\title{
Citizen Participation and Local Democracy in Zimbabwean Local Government System
}

\author{
A. F. Chikerema. \\ Midlands State University Zimbabwe Department: Local Governance Studies \\ Registered PhD student at Nelson Mandela Metropolitan University
}

\begin{abstract}
For the last twenty years, the concept of citizen participation and local democracy has largely been used in the local government discourse. These concepts are heavily related to the rights of citizens and democratic governance. Linking citizen participation to local government raises fundamental and normative questions about the nature of democracy and the skills and strategies for achieving it. This paper seeks to explore literature related to the dynamics and avenues of citizen participation and local democracy in Zimbabwean local government system. Factors which promote citizen participation and local democracy will be discussed including the issue of local government elections, participatory budget in local authorities, consultative forums, public hearings, existence of civil society organisations as well as the formal structures which exist within the local government institutions.

Key Terms: Citizen participation, active participation, passive participation, local democracy and local government Conceptualization of key terms.
\end{abstract}

\section{Citizen participation}

Citizen participation is a desired and necessary part of community development and should be encompassed in any policy formulation process. According to the $\operatorname{ACPD(2006)~participation~means~taking~part~}$ as an individual and as a community in decision making at each step of the development process. This entails that all citizens should be able to participate actively in the local democratic process for any development process to yield fruitful results.Lisk (1985) further defines participation as the involvement of the broad masses of population in the choice, execution and evacuation of programmes and projects that are designed to bring out significant upward movement in the living standards of people. He also observed that the concept of participation relates to the involvement of the broad mass of the population to influence decision making in favour of popular needs and aspirations.Makumbe (1996) also viewed beneficiary citizen participation as only being meaningful for the masses if they are effectively involved at the various levels of the development process. A classical example is that if the poor are engaged in policy planning together with local governments more pro active and efficient policies to address the concerns of the marginalised citizens can be identified. There are mainly two types of participation that is active and passive participation.

\section{Active and passive participation}

The United Nations publication as cited in Makumbe (1996) observed that active participation requires time to attend meetings, vote and inform oneself about issues. Active participation goes beyond mere choice making from predetermined alternatives. Passive participation largely pertains to such choice making and even manipulation of the masses by those who will have critical decisions in the first place. According to the United Nations(1967) if people are continuously expected to be passive recipients of government programs, policy and projects,they tend to shun participation and lose interests in the programmes which lead to failure and underdevelopment of local communities.

\section{Local Democracy}

All citizens should be able to participate actively in the local democratic process. According to Fung (2001:41) local democracy gives citizens the freedom to participate in making decisions that are locally appropriate and serve the needs of the local community. Local democracy simply means rule by the people, giving people a say in the decisions that affect their lives and access to resources that are theirs. The UNECA Executive secretary as cited in Makumbe (1996) observed that the democratisation of the development process, by which we mean the empowerment of the people, their involvement in decision making, in the implementation process is a "condition sine qua non" for socio-economic recovery and transformation. This simply means that the involvement of people in decision making results in the democratisation of the development process. 
The parliamentary Assembly of Europe Resolution 1121 (1997) on instruments of citizen participation states that a truly living democracy depends on the active contribution of all citizens. Their participation in every aspect is thus a decisive factor for the smooth functioning of democratic institutions. The $\operatorname{ACPD}(2003)$ defined democracy more broadly as the full participation of all citizens in political ,economic, social and cultural decision making through appropriate laws, policies institutions, processes and attitudes in a way which promotes equality, the growth of individuals and the well being of communities. Local democracy is basically about sharing power decisions and resources fairly.

\section{Local government}

Local government is a product of devolution as a dimension of decentralisation. Gomme (1987:1-2) defines local government as that part of the whole government of a nation or state which is administered by authorities subordinate to state authority, but elected independently of control by the state authority, by qualified persons resident or having property in certain localities which have been formed by communities having a common interest and common history. Meyer (1978:10) defines local government as local democratic governing unity within the unitary democratic system of a country, which are subordinate members of the government vested with prescribed, controlled governmental powers and sources of income to render specific local services and develop, control and regulate the geographic, social and economic environment of defined local area.

One has to note that whilst local governments are actually not independent of central government control, they enjoy only relative autonomy due to the division of responsibilities for services between central and local government and it should be captured that the division of these responsibilities is a political or policy issue. According to Mawhood (1993:66) local government is the third tier or level of government deliberately created to bring government closer to the grassroots population and gives these grassroots structures give a sense of involvement in the political processes that control their daily lives. The existence of local government has always been defended on the basis that it is a crucial aspect of the process of democratisation and intensification of mass participation in the decision making process. It is furthermore argued that no political system is considered to be complete and democratic if it does not have a system of local government.

There are several preconditions that determine successful relationship between central and local government as indicated by the World Bank (1989:88) and Heymans and Totemeyer (1988:6) which are:

(a) The need and urge for a strong system of local government in a democratic political environment;

(b) That local government be allowed to play a vital role as a full partner in regional and national development;

(c) A fair division of financial resources between central, regional and local bodies;

(d) A fair division of human resources between central and local government;

(e) Formal and effective checks and balances between central and local government;

(f) Full and adequate consultation and regular flow of accurate information at and between all level;

(g) The full participation of each citizen ,irrespective of race and gender at all levels of administration and government thus ,the extension of democracy to all spheres of government;

(h) Political and social harmony.

Local government should be seen as the cornerstones in the structure of a democratic political system since it serves as a vehicle for intelligent and responsible citizenship.

\section{Literature Review}

If the Zimbabwean system of government is to function properly, citizens must actively participate in its operations at all levels, but especially in the local government system. Local officials have both a responsibility and a stake in keeping citizens fully informed about local programmes and activities and giving them clear opportunities to play meaningful roles in determining and implementing local public policy (Smith:1983). The history, tradition, development patterns of local government in Zimbabwe is based on a belief that a responsive and responsible citizenry will maintain a vigorous, informed and continous participation in the processes of local government. A basic principle, upon which the local government, with its broad home rule authority is constructed, is that local community values can be fostered and served(Oluwu:2006). Assuring meaningful participation by citizens in government at all levels in the face of complexity of contemporary society is one of the great challenges of African democracy.

The individual citizen in the Zimbabwean local government system has numerous ways to influence policies and practices and they are given space to have a say in institutional issues. These are the avenues allowing for citizen participation in the local government system and encompasses the following aspects; local government elections, local authorities participatory budgeting, consultative forums, public hearings, open meetings of councils and legislative bodies, joining associations like the Civil Society organisations as well as the development committees within local communities such as the Village Development committee(VIDCO),Ward Development Committee(WADCO), Rural District Development 
Committee(RDDC),Provincial Development Committee(PDC). All local officials have a basic duty to assure that citizens have ways to participate actively and meaningfully in Local Government affairs and this fosters the aspect of democracy within the system.

\section{Local government elections}

A broad base of participation in local government forms the foundation of our working democracy. Electoral process is one of many ways in which individual citizens may express their views at the local level. Elections play a pivotal role in strengthening decentralised governance, this greatly facilitate public or citizen participation by determining the nature and type of officials to hold public offices. According to Braun and Grote (2000) participatory local governments are more responsive to local needs, elected officials are more accountable and responsive to the needs of the public and they are involved in decision making. Muriisa (2007) also state that decentralisation or the local government system enables people to voice their needs and access certain resources through their elected representatives and as well enhances efficiency through reduced bureaucracy. By this one can observe that citizens are given space to select officials of their choice who best articulates their felt needs and this greatly strengthen the issue of local democracy as well as cementing decentralised governance.

\section{Participatory Budgeting}

In Zimbabwean local government system participatory budgeting is yet another platform in which the ordinary citizens are given space to effect any amendments and inputs which may result in development. This greatly strengthens fiscal decentralisation through allocation of responsibilities to decentralised agencies. Participatory budgeting is a process of democratic deliberations and decision making in which ordinary citizens decide how to allocate part of municipal or public budget. It characterised by several design features that is: identification of spending priorities by community members, election of budget delegates to represent different communities and vote on spending priorities and the implementation of local direct impact community projects. In the case of Zimbabwe local government system, according to the Local government Acts budget proposals are published in three issues of the newspaper so as to give the public a chance to scrutinise the budget.Moreso according to the Urban Councils Act (2006) participatory budget is part of the overall strategic effort to promote local democracy in local authorities and its main objectives are: to promote civic interest and participation in local governance, to involve the community in generating self sustaining livelihoods options as well as to promote accountability and transparency in local public finance and budgeting. Participatory budgeting is a process of democratic deliberations, decision making and participatory democracy in which ordinary citizens decide how to allocate part of a municipal of public budget. This therefore ensures a guided budget in a decentralised form of governance and as well ensuring participation and promotes local democracy within the local government system.

Nkala (2004) views the budget as a public fiscal policy instrument which is essentially a mechanism of how fiscal resources will be mobilised and public goods and services allocated. Similarly Doerr $(1998 ; 45)$ defined the budget as a statement of expected revenues and laid expenditures for a fiscal period. The public citizens should be part of the budget process of their areas so that they can put their desires and ensure that money is also spent on their needs as well.

\section{Consultative Forums and Public Hearings}

Consultative forums in the Zimbabwean local government system also ensure that participation is encouraged and this greatly boosts administrative decentralisation which involves deconcentration and delegation of power from central to local government. According to Saito (1999) in councils there are consultative forums for local decision making. Through elected representatives proposals are channelled to the legislative bodies, all districts are expected to compile district development plans which reflect grassroots needs. Local administrators report to local council officials who in turn account to the people. These accountability procedures are reflective of the democratic process in service provision. The planning process and accountability procedures reflect popular participation in initiating and implementing programmes.

\section{Formal Structures within the Zimbabwe local government institution.}

Formal structures within local government also enhance citizen participation as well as fostering local democracy. In the Zimbabwean local government system structures for popular participation in development planning were outlined in the Prime Minister Directive of 1984/85 which provided the basis for a hierarchy of representative bodies at the village, ward, , district, provincial and national level. According to the Traditional Leaders Act Chapter 29;17 a number of development committees exist within traditional leaders institution including the Village Development Committee(VIDCO), Ward Development Committee(WADCO), Rural District Development Committee(RDDC),Provincial Development Committee(PDC) these are elected bodies 
with responsibility for defining local needs. According to Francis and James (2003) regular village meetings are held to discuss use of local resources where all adult members of the community are expected to participate.

\section{Existence of Civil Society (CS) Organisations}

Civil Society Organisations also encourages participation and this therefore strengthens political decentralisation. It implies that there is the opening of space to accommodate civil and political liberties and institutional pluralism. According to Reddy (1999) participation would therefore mean that people organise themselves, accept responsibilities and become involved in local decision making. In Zimbabwe the local government system is characterised by a large number of Non Governmental Organisations (NGOs).These organisations play a pivotal role in complementing government efforts that is provision of efficient service delivery and as well facilitating local participation. Churches in Zimbabwe represent a good example as they are involved in active management of the education and health sector in most districts.

\section{Conclusion}

This discussion focussed on citizen participation and local democracy in Zimbabwean local government system. Strengthening of participation in local governance has to do with strengthening of direct citizen involvement in decision making by individuals or groups in public activities often through local government elections, participatory budgeting, Civil Society organisations, consultative forums and public hearings as well as formal structures within the Local Government institutions such as the VIDCOs,WADCOs,RDDCs,PDC which ensures citizen active participation as well as steering strong local democracy.

\section{References}

[1]. Africa Community Publishing and Development Trust (2006): Strengthening citizen participation in local decision making, Fingerprint Cooperative Ltd, Cape Town, South Africa.

[2]. Braun, V.J and Grote (2000), 'Does Decentralisation serve the poor?'Paper read at IMF Conference on Fiscal Decentralisation; Washington DC, 20-21 November

[3]. Doer J.E. (1998), Dictionary of Public Administration, Kualar Lumpur, Golden Books Centre

[4]. Fung, A. (2006), 'Varieties of participation in Complex Governance', Public Administration Review-Washington DC-66: 66-75

[5]. Lisk, F (1985_popular participation in Planning for Basic Needs, Blackmore Press, Longhead.

[6]. Nkala P, (2004), the social Sector and the National Budget. A centre on Social Welfare,Education, Agriculture and the Informal Sector in Zimbabwe, A paper prepared for the budget process workshop at Holiday Inn Bulawayo.

[7]. Makumbe, J (1996) Participatory Development, University of Zimbabwe Publications, Harare

[8]. Muriisa, R.C (2007) NGOs and Rural Development in Uganda, MPhil thesis, monograph: University of Bergen; Norway.

[9]. Saito, F.C (1999), Decentralisation in Uganda: Challenges for the $21^{\text {st }}$ Century: Copenhagen: DANIDA.

[10]. Urban Councils Association of Zimbabwe (2006), Best Practices in Participatory Budgeting for five cities in Zimbabwe, UCAZ Publications, Harare.

[11]. Reddy, P.S (ed) (1999) Local government and Democratisation: A review of the SourthernAfrica Region; Cape Town: Juta and Co Ltd

[12]. United Nations Development Programme (1996) the role of participation and partnership in decentralised governance; New York: Prentice Hall. 